\title{
BUOYANT TITRATION OF BOVINE MERCAPTALBUMIN CHEMICALLY MODIFIED AT THE CARBOXYL GROUPS
}

\author{
by \\ IB SVENDSEN \\ Department of Chemistry, Carlsberg Laboratory, Gamle Carlsberg Vej 10 - DK-2500 Copenhagen, Valby and \\ The University of Redlands, Chemical Department, Redlands California 92373, U.S.A.
}

Key words: Buoyant titration, density gradient, ultracentrifugation, carboxyl groups, mercaptalbumin.

\begin{abstract}
Bovine mercaptalbumin has been modified at the carboxyl groups by means of I-ethyl-3 (3-dimethylisopropyl) carbodiimide and glycine amide. A stable derivative was obtained after modification of 54 groups. The modified protein differed only slightly from the unmodified one with respect to the optical rotatory dispersion parameters $\mathrm{a}_{0}, \mathrm{~b}_{\mathrm{o}}$ and $\lambda_{c}$. This preparation was studied in the analytical ultracentrifuge in a $\mathrm{CsCl}$ gradient in the $\mathrm{pH}$-interval from 2 to 11 . The buoyant densities were determined and compared with those of the unmodified protein in the same $\mathrm{pH}$-interval. The contribution from the carboxyl groups to the buoyant density is discussed and compared with results obtained with other proteins and synthetic polypeptides.
\end{abstract}

\section{INTRODUCTION}

The study of nucleic acids by the density gradient sedimentation equilibrium technique has provided useful information about the physico-chemical properties of these macromolecules (5). However, the technique is applicable also to proteins and has been described in detail for these macromolecules by IFFT $(11,12)$. The nbuoyant density,$\rho_{0}$, which is the parameter determined in this type of ex- periment is in the case of proteins strongly dependent on $\mathrm{pH}$. This was clearly demonstrated for ovalbumin for which data could be obtained in the $\mathrm{pH}$ region 2 to 12.5 (13). The change in buoyant density as a function of $\mathrm{pH}$ closely simulated the potentiometric titration curve (14) and the term wbuoyant titration. has been introduced for this type of investigations (12).

From the determined $\rho_{0}$ 's it is possible to es- 
timate the extend of hydration or binding of anions and cations to the proteins. In order to get a better understanding of the contribution from the individual ionizable groups to hydration and ion binding, a series of experiments was initiated in which the buoyant titration curves for synthetic polypeptides $(1,21)$ and proteins $(13,20,25)$ were determined.

The present article is a contribution to these studies. Bovine mercaptalbumin (BMA) ${ }^{2}$ has already been studied in the $\mathrm{pH}$ region 5 to 13 , but due to poor solubility at pH's lower than 5 , buoyant density determinations in this region have been avoided (26). However, since carboxyl groups titrate in the pH interval 2 to 6 and since data for these groups in proteins are available for two proteins only, an alternative way of obtaining buoyant titration data for the carboxyl groups of BMA was attempted. The rationale behind the present study was that chemical modification of the carboxyl groups with a neutral group (e.g. glycine amide) would make them unavailable for titration. The difference in buoyant densities at neutral $\mathrm{pH}$ between chemically modified BMA and unmodified protein would then be a measure of the contribution of the carboxyl groups to the change in $p_{0}$ on titration. A similar approach has been taken by IFFT (13) and ELLIS et al. (4) in the study of the lysines in ovalbumin and BMA, respectively.

\section{MATERIALS AND METHODS}

\subsection{Materials.}

Bovine serum mercaptalbumin (BMA), Nutritional Biochemical Company, twice crystallized, lot $\mathrm{nr} 8915$, was purified according to the method of DinTZIS (7) and stored in the freezer at $-20^{\circ} \mathrm{C}$ as a $5 \%$ isoionic solution. Cesium chloride $(\mathrm{CsCl})$ was obtained from Harshaw Chemical Company. The purity was stated to be $99.9 \%$. Glycineamide hydrochloride was bought from Calbiochem as was 1-ethyl-3 (3dimethyl aminopropyl) carbodiimide hydrochloride (EDC). Sephadex G25 was purchased from Pharmacia Fine Chemicals, Sweden. All other reagents used were analytical grade products, and deionized water was used throughout.

\subsection{Modification of carboxyl groups}

The carboxyl groups of BMA were modified according to the method of KosHLAND (6). In a typical experiment $500 \mathrm{mg}$ of glycineamide hydrochloride were dissolved in $4 \mathrm{ml}$ of deionized water in the $\mathrm{pH}$-stat vessel and the $\mathrm{pH}$ was adjusted to about 6 . Two $\mathrm{ml}$ of a $5 \%$ BMA solution were added followed by $40 \mathrm{mg}$ of EDC. The pH was adjusted to 4.75 and kept at this value for 3 hours at $25^{\circ}$. The reaction was terminated by passing the solution over a Sephadex G25 column $(1.6 \times 2.8 \mathrm{~cm})$ equilibrated with $10^{-3} \mathrm{M}$-Na-phosphate buffer, $\mathrm{pH}$ 7.0 , in the cold room. The same buffer was used for elution and the flow rate was $70 \mathrm{ml} / \mathrm{hr}$. Fractions of $4 \mathrm{ml}$ were collected and those containing protein, as determined by measurements of optical density at $280 \mathrm{~nm}$, were pooled and frozen. In preliminary experiments the protein which had passed over a Sephadex column was subjected to extensive dialysis in order to assure that all glycine, which was not incorporated in the protein, was removed. No difference in the glycine content of modified BMA was detected between gelfiltered and gelfiltered plus dialyzed protein.

\subsection{Amino acid analysis}

The degree of modification was determined by amino acid analysis according to the method of SPACKMAN, MOORE and STEIN (22). Acid hydrolyses were made in $6 \mathrm{~N}-\mathrm{HCl}$ in sealed, evacuated tubes and the analysis performed on a Beckman amino acid analyzer Model 118. The degree of modification of carboxyl groups was established as the difference in glycine content between native and modified BMA. Fortunately, BMA contains only 16 moles of glycine per mole of BMA, which makes the determination of incorporated glycine amide residues quite reliable, since about 100 carboxyl groups potentially are reactive.

2) Abbreviations used: BMA = bovine mercaptalbumin, EDC = 1-ethyl-3 (3-dimethylaminopropyl) carbodiimide, hydrochloride. 


\subsection{Absorption measurements}

were performed with a Cary 14 recording spectrophotometer. Concentrations of native BMA solutions were calculated using $O$. D. $\frac{0.1 \%, 1 \mathrm{~cm}}{280 \mathrm{~nm}}=0.667$ (27). Concentrations of solutions of modified BMA were determined by amino acid analysis.

\subsection{Spectropolarimetric measurements}

were done on a Perkin-Elmer spectropolarimeter model 241 equipped with a $10 \mathrm{~cm}$ waterjacketed microcell kept at $25^{\circ}$. The optical rotations at 578, 546, 436 and $345 \mathrm{~nm}$ were recorded and the parameters $[\alpha] \lambda_{c}, a_{o}$ and $b_{o}$ calculated the usual way (15). In the calculations of $a_{o}$ and $b_{o}$ from the Moffitt equation, $a$ value of $218 \mathrm{~nm}$ was adopted for $\lambda_{\mathrm{o}}$ (19).

\subsection{Refractive indices}

were measured on a Bausch and Lomb, Abbé Model $3 \mathrm{~L}$ refractometer at $25^{\circ}$.

\section{7 pH-measurements}

were made with a Beckman Research $\mathrm{pH}$ meter, Model 1019 equipped with a combination electrode (39183). Standardization of the instrument was made with Beckman Standard Buffers.

\subsection{Ultracentrifuge studies}

were performed in a Spinco Model E ultracentrifuge using the schlieren optics. An An$F$ aluminum rotor was used in conjunction with standard $12 \mathrm{~mm}$ Kel-F centerpieces equipped with $0^{\circ},-1^{\circ}$ and $-2^{\circ}$ wedge windows. The temperature was kept at $25^{\circ}$ and the angular velocity was $50740 \mathrm{rev} . / \mathrm{min}$.

Solutions containing protein, $\mathrm{CsCl}$ and buffer were prepared following standard procedures (11). At equilibrium, which was established within 24 hrs, pictures were taken using Kodak metallographic plates and after development enlarged for evaluation with a Beseler Model $23 \mathrm{c}$ enlarger. Refractive index and $\mathrm{pH}$ were measured both before and after each run. Only small differences were noted, but in all instances the latter values were used in calculating the buoyant densities. The calculations were performed by a computer for which a program was written in BASIC.

\section{RESULTS AND DISCUSSION}

\subsection{Extent of modification}

Preliminary experiments, in which the reaction mixture was left for an extended period of time, showed that it was possible to modify about 90 carboxyl groups in BMA as judged from the incorporation of glycine residues. However, this high degree of modification rendered the protein quite unstable and a continous precipitation of material took place when a gelfiltered preparation was left in the cold-room. A reaction time of $3 \mathrm{hrs}$ was finally chosen since in this case a stable but still reasonably extensively modified derivative was obtained. The amino acid composition of such a preparation is given in Table 1 together with that of the unmodified protein. It is seen that 54 glycyl residues have been incorporated.

Although modification of tyrosyl residues $a$ priori cannot be excluded (2) it appears unlikely in the present study. EDC modified tyrosyl residues are partially stable to acid hydrolyses (3). Amino acid analysis of BMA modified with EDC, but with omission of glycineamide, showed no decrease in tyrosine content (Table 1). Although small changes were noted in the UV-spectrum of modified BMA this was not changed upon treatment with hydroxylamine which was to be expected if modification of tyrosyl residues had taken place (2). It is therefore assumed that the number of glycines incorporated reflects modification of carboxyl groups, only.

\subsection{Conformational changes}

In order to assure that no major changes in the three dimensional structure had resulted from modification of 54 carboxyl groups the optical rotation of the modified BMA was measured at 4 wavelengths. In Table 2 are shown $[\alpha]_{\lambda}, \lambda_{c}$ (calculated from the Drude-equation), and $b_{0}$ and $a_{0}$ (calculated from the Moffitt equation). All the ORD data were obtained at $\mathrm{pH}$ between 7.0 and 7.3. The concentration of $\mathrm{CsCl}$ was identical to the one used in the ultracentrifuge studies at the same $\mathrm{pH}$. Included in the table are data obtained with unmodified BMA. The identical values of $\lambda_{c}$ in all four cases indicate that no major change in the tertiary structure has taken place by either modification of 
Table I

Amino acid composition of native bovine mercaptalbumin and two chemically modified derivatives.

\begin{tabular}{|c|c|c|c|c|c|}
\hline Amino acid & $\begin{array}{l}\text { Native } \\
\text { BMA }\end{array}$ & $\begin{array}{l}\text { Modif. } \\
\left.\text { BMA }^{1}\right)\end{array}$ & $\begin{array}{l}\text { Modif. } \\
\text { BMA }^{2} \text { ) }\end{array}$ & $\begin{array}{c}\text { SPAHR- } \\
\left.\text { EDSALL }^{3}\right)\end{array}$ & $\begin{array}{c}\text { KING- } \\
\left.\text { SPENCER }{ }^{4}\right)\end{array}$ \\
\hline $\begin{array}{l}\text { Lysine } \\
\text { Histidine } \\
\text { Arginine } \\
\text { Aspartic acid } \\
\text { Threonine } \\
\text { Serine } \\
\text { Glumatic acid } \\
\text { Proline } \\
\text { Glycine } \\
\text { Alanine } \\
1 / 2 \text { Cystine } \\
\text { Valine } \\
\text { Methionine } \\
\text { Isoleucine } \\
\text { Leucine } \\
\text { Tyrosine } \\
\text { Phenylalanine }\end{array}$ & $\begin{array}{r}56.8 \\
18.2 \\
22.9 \\
56.5 \\
32.5 \\
31.0 \\
79.7 \\
28.9 \\
17.1 \\
47.9 \\
26.6 \\
32.5 \\
4.0 \\
21.2 \\
58.4 \\
20.2 \\
24.9\end{array}$ & $\begin{array}{r}57.3 \\
16.0 \\
23.2 \\
56.1 \\
33.1 \\
30.0 \\
82.9 \\
31.8 \\
71.1 \\
46.7 \\
28.7 \\
35.1 \\
4.0 \\
13.3 \\
61.7 \\
20.3 \\
27.0\end{array}$ & $\begin{array}{r}57.1 \\
16.9 \\
22.6 \\
55.5 \\
33.2 \\
31.0 \\
81.1 \\
29.7 \\
16.9 \\
47.5 \\
30.8 \\
32.9 \\
4.1 \\
13.5 \\
62.5 \\
20.0 \\
27.0\end{array}$ & $\begin{array}{c}62 \\
17 \\
22-23 \\
54 \\
34 \\
26 \\
77-78 \\
30 \\
16 \\
46 \\
36 \\
36-37 \\
4 \\
14 \\
62 \\
20 \\
27\end{array}$ & $\begin{array}{r}58 \\
17 \\
23 \\
54 \\
32 \\
26 \\
80 \\
28 \\
15 \\
44 \\
36 \\
35 \\
4 \\
14 \\
62 \\
19 \\
26\end{array}$ \\
\hline
\end{tabular}

1) Modified with EDC and glycineamide. $\left.{ }^{2}\right)$ Modified with EDC alone. ${ }^{3}$ ) From ref. (23). ${ }^{4}$ ) From ref. (17). The values in column $2-4$ are average or extrapolated values from 24,48 and 72 hrs hydrolysates. Tryptophan was not determined.

carboxyl groups or addition of $\mathrm{CsCl}$. However, the $b_{o}$ values indicate a decrease in helical content upon modification, but not by addition of $\mathrm{CsCl}$. On the other hand chemical modification does not seem to influence the $a_{0}$ value while a change is observed when $\mathrm{CsCl}$ is added to either unmodified or modified BMA. The same observation is made for $[\alpha]_{s 78}$. It should be pointed out that ORD-studies have only been performed at pH's near neutrality, no systematic studies have been conducted over the whole $\mathrm{pH}$-range where the ultracentrifuge studies were performed. Anyhow, the changes in tertiary structure as a result of the chemical modification were considered so small that further studies in the ultracentrifuge would be meaningful.

\subsection{Density gradient experiments}

The results of the density gradient experiments with BMA in which 54 carboxyl groups have been modified are presented in Fig. 1 together

Table II

ORD parameters for native bovine mercaptalbumin and mercaptalbumin modified at carboxyl groups.

\begin{tabular}{l|c|c|c|c}
\hline & $-[\alpha]_{578}$ & $\lambda_{\mathrm{c}}$ & $-\mathrm{a}_{\mathrm{o}}$ & $-\mathrm{b}_{\mathrm{o}}$ \\
\hline Native BMA, literature ${ }^{\text {) }}$ & - & - & 336 & 253 \\
Native B MA, this study & 65.4 & 265 & 328 & 248 \\
Native BMA in 3M CsCl & 59.5 & 265 & 285 & 254 \\
COOH-modified BMA & 63.0 & 265 & 326 & 190 \\
COOH-modified BMA in 3M CsCl & 56.4 & 265 & 270 & 200 \\
\hline
\end{tabular}

1) From ref. (19). 


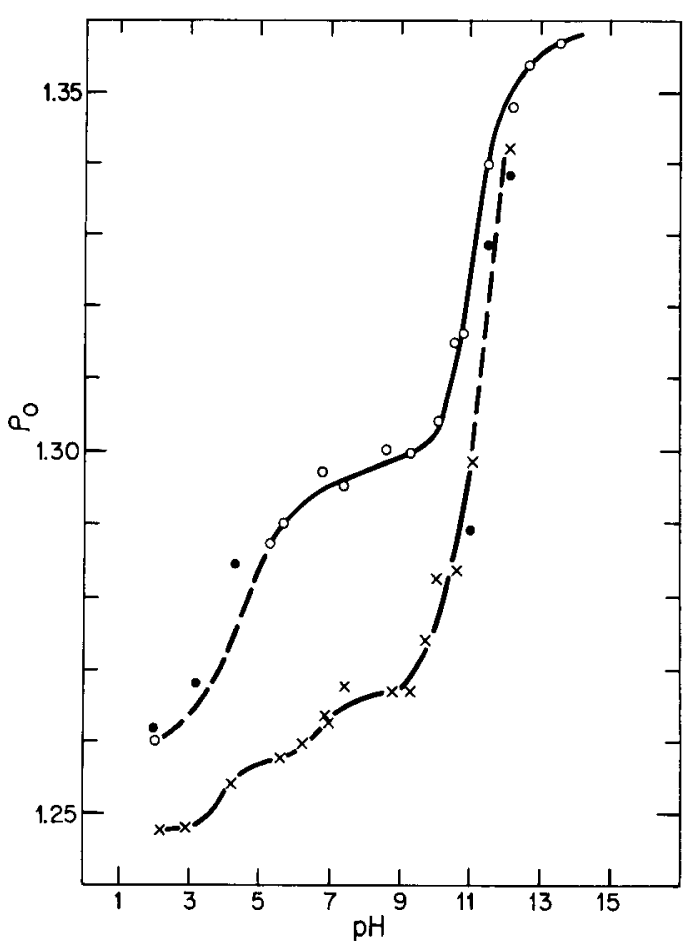

Figure 1. Buoyant titration curve for: $-x$ - bovine mercaptalbumin chemically modified at 54 carboxyl groups, and - $\mathrm{O}-$ native bovine mercaptalbumine. All runs were conducted at $25^{\circ}$. - - indicates buoyant densities of precipitated protein. The curve for native bovine mercaptalbumin was adopted from reference (4).

with those from experiments with native BMA. The curve for the unmodified protein above $\mathrm{pH}$ 5 is taken from ElLIS et al. (4). The same purified preparation of BMA has been used as the starting material in the two studies.

It is seen that throughout the $\mathrm{pH}$-range covered by both sets of experiments ( $\mathrm{pH}$ 2-11) $\rho_{0}$ 's calculated for the modified BMA are consistently lower than those calculated for native BMA. Considering experimental errors the difference in $\rho_{0}$ from $\mathrm{pH} 5$ to 11 appears to be nearly constant, $\Delta \rho_{0} \sim 0.030 \mathrm{~g} / \mathrm{ml}$. While native BMA precipitated at $\mathrm{pH}$ lower than 5 , the modified protein remained in solution at $\mathrm{pH}$ as low as 2 . Although the native protein precipitated below $\mathrm{pH} 5$ it was still possible to obtain values for $\rho_{0}$. Three such determinations are included in the curve (Fig. 1). At pH 2 the protein begins to redissolve and both $p_{0}$ (prec.) and $p_{0}$ (sol.) were determined. At this $\mathrm{pH} \rho_{0}$ (sol.) of the native BMA was $0.012 \mathrm{~g} / \mathrm{ml}$ higher than $\rho_{0}$ of the modified protein. On the other hand precipitation of modified BMA was observed at pH 10 and above, a phenomenon not seen with native BMA. In the experiments conducted at pH 10.0 and 10.6 both precipitated and soluble protein were present simultaneously while at pH 11.5 only precipitate was observed. Since 54 negative charges have been removed by the modification of carboxyl groups the isoelectric point of the derivative is expected to be at $\mathrm{pH}$ 11. The occurrence of precipitate at high $\mathrm{pH}$ is probably due to decreased solubility as well as decreased stability of the modified molecules. It was noted that the precipitate observed in the ultracentrifuge at $\mathrm{pH} 10.0$ ard 10.6 redissolved when the experiment was terminated and the cell shaken. At $\mathrm{pH} 11.5$ the precipitate remained at the end of the run.

The change in $\rho_{0}$ at high $\mathrm{pH}$ shall not be dealt with in any detail in this paper. The contribution of lysyl residues in native BMA to $\Delta p_{0}$ has already been studied by ELLIS et al (4). From Fig. 1, it appears that the sharp rise in $\rho_{0}$ due to titration of lysyl, tyrosyl and (perhaps) arginyl residues starts at the same $\mathrm{pH}$ in the modified BMA which indicates that modified and native BMA have the same structure at high $\mathrm{pH}$.

poly-L-glutamic acid has been used as a model compound for the study of the contribution from carboxyl groups to the change in buoyant density, $\Delta \rho_{0}$, when these groups are titrated (1). It was shown that $\rho_{0}$ increased by $0.195 \mathrm{~g} / \mathrm{ml}$ upon ionization.

$\Delta \rho_{0}$ for the titration of poly-L-aspartic acid has never been measured. It is assumed to be the same as for poly-L-glutamic acid. How close does this value compare to the $\Delta p_{0}$ in proteins in the acid $\mathrm{pH}$ region? Until now results are available for only two proteins: ovalbumin and immunoglobulin IgG. Using the value given above, a theoretical change in buoyant density, $\Delta \rho_{0}$, of $0.026 \mathrm{~g} / \mathrm{ml}$ was calculated for the titration of the carboxyl groups in ovalbumin (13). This figure compared fairly well with the observed $0.033 \mathrm{~g} / \mathrm{ml}$. With $\mathrm{IgG}$ an even closer agreement was found. In this case the theoretical $\Delta \rho_{0}^{\prime}$ was $0.023 \mathrm{~g} / \mathrm{ml}$ and the observed $0.021 \mathrm{~g} / \mathrm{ml} \mathrm{(20)}$. 
In native BMA $\Delta p_{0}$ upon titration of the carboxyl groups was found to be $0.031 \mathrm{~g} / \mathrm{ml}$ (Fig. 1). From the number of amino acid residues determined in the present study, 585, and a total number of carboxyl groups of 100 $(24,25)$ the change in density, $\Delta \rho_{0}{ }^{\prime}$, can be calculated on the basis of the value obtained for poly-L-glutamic acid as

$\Delta \rho_{0}^{\prime}=\frac{0.195 \times 100}{585}=0.033 \mathrm{~g} / \mathrm{ml}$

A good correspondance between the model compound behavior and experiments with native $\mathrm{BMA}$ is demonstrated.

In the modified BMA only 46 carboxyl groups are available for titration. Therefore, one would expect a

$\Delta \rho_{0}^{\prime}$ of $\frac{0.195 \times 46}{585}=0.015 \mathrm{~g} / \mathrm{ml}$.

The actually observed increase was $0.011 \mathrm{~g} / \mathrm{ml}$. The deviation from the theoretical value has in this case the opposite trend than observed for ovalbumin.

At $\mathrm{pH} 2$ a difference in $p_{0}$ between native and modified BMA of $0.012 \mathrm{~g} / \mathrm{ml}$ is observed. At this $\mathrm{pH}$ all the free carboxyl groups are protonated and those that are modified are uncharged as well. One might therefore expect the buoyant density of native and modified BMA to be identical. That this is not the case is most likely due to the introduction of 54 glycineamide residues, which tend to decrease $p_{0}$ relative to that of native BMA. A similar, although opposite, effect was observed by IFFT after carbamylation of ovalbumin (13). In this case the addition of $-\mathrm{CONH}_{2}$ groups to 18 lysyl residues (transferring them into uncharged homocitrullines) led to a positive change in $p_{0}$ of $0.007 \mathrm{~g} / \mathrm{ml}$ relative to the unmodified protein.

If the difference in $\rho_{0}$ between the native and modified BMA at $\mathrm{pH} 7$ is used to calculate the contribution of carboxyl groups to $\Delta p_{0}$ a correction for the $\rho_{0}$ due to glycineamide is necessary. The difference in $\rho_{0}$ at $\mathrm{pH} 7.0$ is $0.032 \mathrm{~g} / \mathrm{ml}$ which therefore should be corrected to 0.032 $0.012=0.020 \mathrm{~g} / \mathrm{ml}$, assuming that the contribution to $\rho_{0}$ from the glycineamide group is the same at $\mathrm{pH} 2$ and 7 . This value is somewhat higher than the theoretically calculated and almost twice that calculated from the change in the acid $\mathrm{pH}$ region.

The reason for the differences is not immediate apparent. BMA molecules undergo a transition and an expansion at $\mathrm{pH}$ values lower than 4 which might influence the buoyant densities measured in the acid pH-region. However, a good agreement between the results for native BMA and poly-L-Glu was found. The conformational changes in modified BMA in the acid $\mathrm{pH}$-region might be more drastic giving rise to a relatively small change in $\rho_{0}$. At $\mathrm{pH} 7$ both native and modified BMA exist in a more compact form (although ORD-studies showed that small conformational changes had taken place in the modified BMA). The $\Delta \boldsymbol{\rho}_{0}$ for ionization of carboxyl groups determined from the difference between native and modified BMA at pH 7 therefore is believed to be a more representative value than the one determined from $\Delta \rho_{0}$ in the acid region.

A comparison between the $\Delta \rho_{0}$ 's obtained to date for the ionization of proteins and polypeptides is made in Table 3. All data are normalized to the value that would have been obtained if the protein consisted of glutamic acid residues only. The following equation was used:

$\Delta \rho_{0}^{*}=$

$\Delta \rho_{0} \times \frac{\text { total number of amino acid residues }}{\text { number of carboxyl residues }} \mathrm{g} / \mathrm{ml}$

In view of the empirical equation used, the agreement between the results obtained from the three proteins and the model peptides seems quite good. A comment is appropriate with regard to poly-Glu ionization. During the ionization a phase shift from insoluble to soluble form takes place (1). The agreement between $\Delta \rho_{0}$ from this polymer and the $\Delta \rho_{0}$ 's of the proteins is found for the total change in $p_{0}$ of poly-Glu. When the insoluble and soluble form of poly-Glu are investigated separately the corresponding $\Delta \mathrm{p}_{0}$ 's for the two phases can be calculated as 0.730 and $0.073 \mathrm{~g} / \mathrm{ml}$, respectively (1). If the intermediate value of $0.195 \mathrm{~g} / \mathrm{ml}$ found for the overall ionization of poly-Glu was connected to the phase-shift only, one might expect the determined values for proteins and 
Table III

Change in buoyant density on the ionization of carboxyl groups.

$\mathrm{COOH}$ in poly-Glu ${ }^{60} \mathrm{Lys}^{40}$

$\mathrm{COOH}$ in poly-Glu${ }^{55} \mathrm{Tyr}^{45}$

$\mathrm{COOH}$ in poly-Glu${ }^{1}$ )

$\mathrm{COOH}$ in poly-Glu (insoluble).

$\mathrm{COOH}$ in poly-Glu (soluble)

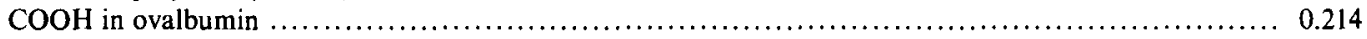

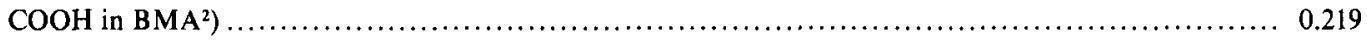

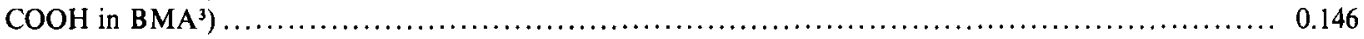

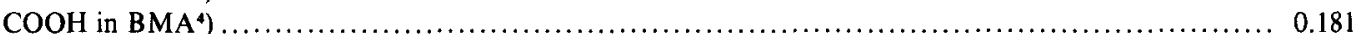

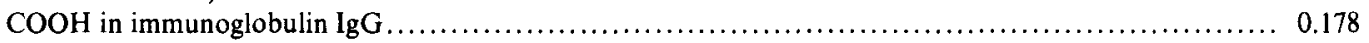

1) Taken as the difference between the flat portions of the $\rho_{\mathrm{o}}$ vs $\mathrm{pH}$ curve at high and low $\mathrm{pH}$.

${ }^{2}$ ) Calculated from the corrected difference at $\mathrm{pH} 7$ between the buoyant density titration curves for native and COOH-modified BMA.

$\left.{ }^{3}\right)$ Calculated from the difference in $\rho_{o}$ of $\mathrm{COOH}$-modified BMA between $\mathrm{pH} 2$ and 6.

4) Calculated from the difference in $\rho_{o}$ of native BMA between $\mathrm{pH} 2$ and 6.

polypeptides which do not undergo phase-shifts from $\mathrm{pH} 2$ to 6 , to lie close to one of the extreme values determined for poly-Glu. This is not the case. Thus poly-Glu ${ }^{60} \mathrm{Lys}^{40}$ is soluble throughout the titration range, but has $\Delta p_{0}$ of the same magnitude as poly-Gluss $\mathrm{Tyr}^{45}$ which is insoluble throughout the titration range of the carboxyl groups ${ }^{3}$. The normalized $\Delta \rho_{0}$ for the carboxyl groups of all the soluble proteins also are far from the $0.073 \mathrm{~g} / \mathrm{ml}$ obtained with soluble poly-Glu.

In the experiments with ovalbumin at low $\mathrm{pH}$ IFFT (13) observed small amounts of precipitated material both with native and carbamylated protein. In both cases, $\rho_{0}$ of the insoluble material was $0.010 \mathrm{~g} / \mathrm{ml}$ higher than that of the soluble protein. For native BMA at pH 2 both soluble and precipitated protein is present. Also in this case the precipitate is more dense, but the difference in $\rho_{0}$ is only about $0.002 \mathrm{~g} / \mathrm{ml}$. However, the precipitate observed with modified BMA at high pH's had $\rho_{0}$ 's which were lower than that observed with soluble modified BMA when both phases were present simultaneously. Thus at $\mathrm{pH} 11 \rho_{0}$ (prec.) was 1.290 and $p_{0}$ (sol.) was 1.299 , while at $\mathrm{pH} 12.2 \mathrm{p}_{0}$ (prec.) was 1.338 v.s. 1.342 for the soluble derivative. At the present there is no way to comment on the relative importance of changes in hydration or ion binding for the observed differences.

The number of $\mathrm{Cs}^{+}$and $\mathrm{Cl}^{-}$ions bound to a protein can be calculated from the following equations:

$$
\begin{aligned}
& \rho_{0}=\frac{1+\left(v_{\mathrm{Cl}^{-}}+\mathrm{NNC}\right)\left(\mathrm{M}_{\mathrm{Cs}}+/ \mathrm{M}_{3}\right)+v_{\mathrm{Cl}^{-}}\left(\mathrm{M}_{\mathrm{Cl}}-/ \mathrm{M}_{3}\right)+\Gamma_{*}^{\prime}}{\overline{\mathrm{v}}_{3}+\left(v_{\mathrm{Cl}^{-}}+\mathrm{NNC}\right)\left(\mathrm{M}_{\mathrm{Cs}}+/ \mathrm{M}_{3}\right) \overline{\mathrm{v}}_{\mathrm{Cs}}++v_{\mathrm{Cl}^{-}}\left(\mathrm{M}_{\mathrm{Cl}} / \mathrm{M}_{3}\right) \overline{\mathrm{v}}_{\mathrm{Cl}^{-}}+\Gamma_{*}^{\prime} \mathrm{v}_{1}} \\
& \rho_{0}=\frac{1+v_{\mathrm{Cs}}+\left(\mathrm{M}_{\mathrm{Cs}}+/ \mathrm{M}_{3}\right)+\left(v_{\mathrm{Cs}}++\mathrm{NPC}\right)\left(\mathrm{M}_{\mathrm{Cl}}-/ \mathrm{M}_{3}\right)+\Gamma_{*}^{\prime}}{\overline{\mathrm{v}}_{3}+v_{\mathrm{Cs}}+\left(\mathrm{M}_{\mathrm{Cs}}+/ \mathrm{M}_{3}\right) \overline{\mathrm{v}}_{\mathrm{Cs}}++\left(v_{\mathrm{Cs}}++\mathrm{NPC}\right)\left(\mathrm{M}_{\mathrm{Cl}^{-}} / \mathrm{M}_{3}\right) \overline{\mathrm{v}}_{\mathrm{Cl}^{-}}+\Gamma_{*}^{\prime} \mathrm{v}_{1}}
\end{aligned}
$$

3) The value of $0.249 \mathrm{~g} / \mathrm{ml}$ was calculated by SHARP et al. (21) from the slope of a $p$ vs degree of ionization plot. This plot was found unsatisfactory by the same authors due to scatter of the points. If the above calculations are made on the basis of po between pH 2 and 6 a value of $0.354 \mathrm{~g} / \mathrm{ml}$ is obtained which is somewhat closer to, but still far from the $0.730 \mathrm{~g} / \mathrm{ml}$ obtained for insoluble poly-Glu. 
where eq. (1) applies above the isoelectric point of the protein and eq. (2) applies below. $p_{0}=$ observed buoyant density, $v_{\mathrm{Cl}^{-}}$and $v_{\mathrm{Cs}^{+}}{ }^{+}$are numbers of chloride and cesium ions bound, $\mathrm{M}_{\mathrm{Cs}}{ }^{+}, \mathrm{M}_{\mathrm{Cl}^{-}}$and $\mathrm{M}_{3}$ are the molecular weights of $\mathrm{Cs}^{+}, \mathrm{Cl}^{-}$and the protein, $\overline{\mathrm{v}}_{3}=$ partial specific volume of protein, $\bar{v}_{\mathrm{Cs}^{+}}$and $\bar{v}_{\mathrm{Cl}^{-}}=$the partial specific volumnes of cesium and chloride at $25^{\circ}$ (10), NNC and NPC = net negative and net positive charge. $\Gamma_{*}^{\prime}$ in $\mathrm{g} \mathrm{H}_{2} \mathrm{O}$ per $\mathrm{g}$ protein is the net hydration of the protein-salt complex. In this equation (which has been derived thermodynamically by SHARP et al. (21), $\rho_{0}$ is known, and $\overline{\mathrm{v}}_{\mathrm{Cl}^{-}}$and $\overline{\mathrm{v}}_{\mathrm{Cs}}+$ can be obtained from ref. (10). When equations (1) and (2) are used for the calculation of $\Gamma_{*}^{\prime}$ it is assumed that $\bar{v}_{3}$ is constant throughout the pH-region studied. This assumption is probably an oversimplification, but no separate studies of the variation of $\vec{v}_{3}$ with $\mathrm{pH}$ in high salt concentrations have been performed. The apparent specific volume for BMA has been determined at the isoelectric point in $2.47 \mathrm{M}-\mathrm{CsCl}$ by pycnometry (8). The value $0.736 \mathrm{~g} / \mathrm{ml}$ obtained does not differ from the one determined in the absence of $\mathrm{CsCl}$. This value was used in the following calculation of $\Gamma_{*}^{\prime}$ of the protein-salt complex.

Potentiometric titration of a protein under the same conditions as in the ultracentrifuge experiments provides the NPC or NNC of eq. (1) and (2), respectively (ref. 14). Such a titration has not been performed in the present study. However, at $\mathrm{pH} 2$ all the carboxyl groups are assumed to be in their protonated form and the protein will carry a positive net charge of 96 . In order to obtain electroneutrality 96 chloride ions must be bound. Using eq. (1) $\Gamma_{*}^{\prime}$ of 0.36 $\mathrm{g}$ of $\mathrm{H}_{2} \mathrm{O} / \mathrm{g}$ of protein-salt complex was calculated for the modified BMA and $0.31 \mathrm{~g}$ of $\mathrm{H}_{2} \mathrm{O} / \mathrm{g}$ of protein-salt complex for the native BMA. These figures are equivalent to about $1350 \mathrm{H}_{2} \mathrm{O}$ molecules/mole of modified BMA and about $1100 \mathrm{H}_{2} \mathrm{O}$ molecules/mole of native BMA.

The preferential hydration, $\Gamma^{\prime}$, which is the minimum amount of water bound by the protein can be calculated from the following equation:

$$
\rho_{0}=\frac{1+\Gamma^{\prime}}{\overline{\mathrm{v}}_{3}+\Gamma^{\prime} \overline{\mathrm{v}}_{1}}
$$

$\overline{\mathrm{v}}_{3}$ being the partial specific volume of the protein and $\bar{v}_{1}$ the partial specific volume of the solvent (assumed to be $1.00 \mathrm{ml} / \mathrm{g}$ for $\mathrm{H}_{2} \mathrm{O}$ ). Calculations showed $\Gamma^{\prime}$ for modified BMA at $\mathrm{pH} 2$ to be $0.33 \mathrm{~g}$ of $\mathrm{H}_{2} \mathrm{O} / \mathrm{g}$ of protein and for the native BMA to be $0.28 \mathrm{~g}$ of $\mathrm{H}_{2} \mathrm{O} / \mathrm{g}$ of protein or about 1220 molecules of $\mathrm{H}_{2} \mathrm{O} /$ mole of modified and 1000 moles of $\mathrm{H}_{2} \mathrm{O} / \mathrm{mole}$ of native BMA, respectively.

It is interesting to note that at $\mathrm{pH} 2$ only a smail difference in $\Gamma_{*}^{\prime}$ and $\Gamma^{\prime}$ for both modified and unmodified BMA is observed. $\Gamma_{*}^{\prime}-\Gamma^{\prime}$, which represents the further solvation due to $\mathrm{Cl}^{-}$ion binding is in both cases about $0.03 \mathrm{~g}$ of $\mathrm{H}_{2} \mathrm{O} / \mathrm{g}$ of protein: In contrast $\Gamma_{*}^{\prime}-\Gamma^{\prime}$ for unmodified BMA at its isoelectric point was shown to be $0.31 \mathrm{~g}$ of $\mathrm{H}_{2} \mathrm{O} / \mathrm{g}$ of protein (9). The reason for the small $\Gamma_{*}^{\prime}-\Gamma^{\prime}$ at $\mathrm{pH} 2$ might be that the 98 $\mathrm{Cl}^{-}$ions are much more loosely bound than the $53 \mathrm{Cl}^{-}$ions at the isoelectrec point.

Since the same number of ions is bound to both modified and native BMA at $\mathrm{pH} 2$ one would expect $\Gamma_{*}{ }^{\prime}$ to be identical for the two proteins. However, a difference corresponding to 235 moles of $\mathrm{H}_{2} \mathrm{O} /$ mole of protein was observed. A similar calculation using the $\Gamma^{\prime} \mathrm{s}$ gave 220 moles of $\mathrm{H}_{2} \mathrm{O} /$ mole of protein. These differences probably reflect changes in hydration number due to the introduction of 54 glycineamide residues. Thus each glycineamide residue binds approximately 4 moles of $\mathrm{H}_{2} \mathrm{O}$.

The increase in $\rho_{0}$ on titration of the carboxyl groups can be caused by 1) a gain in $\mathrm{Cs}^{+}$ions, 2) a loss in $\mathrm{Cl}^{-}$-ions or 3) a change in volume. Each of these possibilities will now be considered separately.

1) In modified BMA 46 carboxyl residues are available for titration. If we assume that the creation of 46 negative charges between $\mathrm{pH} 2$ and 6 leads to binding of $46 \mathrm{Cs}^{+}$-ions a "theoretical $\rho_{0}$ can be calculated:

$$
\rho_{0}=\frac{67000 \mathrm{~g} \text { protein }+(46 \times 132.9) \mathrm{g} \mathrm{Cs}^{+}}{(67000 \mathrm{~g} / 1.248 \mathrm{~g} / \mathrm{ml}) \mathrm{ml}+(46 \times 19.6) \mathrm{ml} \mathrm{Cs}{ }^{+}}=1.339 \mathrm{~g} / \mathrm{ml}
$$


However, a $\rho_{0}$ of $1.259 \mathrm{~g} / \mathrm{ml}$ was observed at $\mathrm{pH}$ 6. Therefore, as expected, the $\mathrm{Cs}^{+}$must be hydrated. If the terms $\times \mathrm{g} \mathrm{H}_{2} \mathrm{O}$ and $\times \mathrm{ml} \mathrm{H}_{2} \mathrm{O}$ are added to the numerator and denominator, respectively, and if $\rho_{0}$ is set to $1.259 \mathrm{~g} / \mathrm{ml}$, it can be calculated that 940 moles of $\mathrm{H}_{2} \mathrm{O}$ must be added concomitantly with the $46 \mathrm{Cs}^{+}$, or 20 water molecules per $\mathrm{Cs}^{+}$. This is an unreasonably high number for hydration of $\mathrm{Cs}^{+}$.

2) If a similar calculation is made assuming the loss of $46 \mathrm{Cl}^{-}$a resulting loss of 4 molecules of water per $\mathrm{Cl}^{-}$is obtained. This number is a reasonable figure for hydration of chloride ions. 3) As already pointed out by KaUzManN (13, 18) at least part of the change in $\rho_{0}$ might be due to a change in volume. From the equation

$\Delta \rho_{0}=\frac{-\Delta V \times \rho_{0}}{V}$

and a $\Delta V=11 \mathrm{ml} / \mathrm{mole}$ of COOH, IFFT (13) calculated that about $2 / 3$ of the change in ovalbumin on ionization was accounted for in this way. The value $-11 \mathrm{ml} /$ mole of $\mathrm{COOH}$ was obtained at low salt concentration and is assumed also to be valid in $3 \mathrm{M}-\mathrm{CsCl}$. A similar calculation for modified BMA shows a $\Delta \rho_{0}$ of $0.013 \mathrm{~g} / \mathrm{ml}$. The observed $\Delta p_{0}$ was $0.011 \mathrm{~g} / \mathrm{ml}$. Thus the change in buoyant density of modified BMA can be explained almost solely in terms of change in volume when the carboxyl groups titrate.

Similar calculations performed with native BMA showed that 18 moles of $\mathrm{H}_{2} \mathrm{O}$ must be bound per $\mathrm{Cs}^{+}$bound or 4 moles of $\mathrm{H}_{2} \mathrm{O}$ lost per $\mathrm{Cl}^{-}$lost when 100 carboxyl groups titrate. Of these possibilities loss of $\mathrm{Cl}^{-}$as the carboxyl groups dissociate is the most likely explanation. When the change in $\rho_{0}$ for native BMA is calculated in terms of change in volume a close agreement with the observed value is observed: $0.029 \mathrm{~g} / \mathrm{ml}$ vs $0.031 \mathrm{~g} / \mathrm{ml}$.

The results of these calculations therefore would indicate that the change in buoyant density between $\mathrm{pH} 2$ and 6 can be accounted for almost exclusively in terms of changes in the volume of both native and modified BMA. It should be pointed out that the calculations involving volume changes are somewhat uncertain in light of the anomalous volume changes which take place in the acid $\mathrm{pH}$ region (see f. ex. KATZ et al. (16)). However, the data obtained in this study together with those obtained by IFFT (13) with ovalbumin stresses the importance of obtaining independent data on $\vec{v}_{3}$ as a function of $\mathrm{pH}$ in high concentrations of salt. Such data would be of great importance for a more conclusive interpretation of data obtained by buoyant titration of proteins.

\section{ACKNOWLEDGEMENTS}

The author wishes to express his appreciation to Professor J. B. IFFT for inviting him to the University of Redlands to do this work and for his critical comments on the manuscript. Also a thank you to Professor OTtesen, Carlsberg Laboratory, for his helpful suggestions. This work was in part supported by Research Grant GM 18871 from the National Institute of General Medical Sciences, Bethesda, U.S.A. Also the financial support from United Breweries, Copenhagen, Denmark and NATO Science Fellowships are gratefully acknowledged.

\section{REFERENCES}

1. Almassy, R., J. S. V. ZiL, L. G. Lum and J. B. IFFT:Buoyant and potentiometric titrations of synthetic polypeptides. I. Six ionizable homopolypeptides in $\mathrm{CsCl}$ solutions. Biopolymers 12 : 2713-2729 (1973).

2. Carraway, K. L. and D. E. Koshland, Jr: Reaction of tyrosine residues in proteins with carbodiimide reagents. Biochim. Biophys. Acta 160: 272-274 (1968).

3. Carraway, K. L. and D. E. Koshland, Jr: Carbodiimide modification of proteins. Methods Enzym. 25: 616-623 (1972).

4. Ellis, D. A., V. Coffman and J. B. IffT: The buoyant titration of native and carbamylated bovine serum mercaptalbumin. Biochemistry 14: 1205-1211 (1975).

5. Hearst, J. E. and C. W. Schmid: Density gradient sedimentation equilibrium. Methods Enzym. 27: 111-127 (1973)

6. Hoare, D. G. and D. E. Koshland, Jr.: A method for the quantitative modification and estimation of carboxylic acid groups in proteins. $J$. Biol. Chem. 242: 2447-2453 (1967).

7. Hughes, W. L. and H. M. Dintzis: Crystallization of the mercury dimers of human and bovine mercaptalbumin. J. Biol. Chem. 239: 845-849 (1964). 
8. IfFT, J. B. and J. Vinograd: The buoyant behaviour of bovine serum mercaptalbumin in salt solutions at equilibrium in the ultracentrifuge. I. The protein concentration distribution by schlieren optics and the net hydration in $\mathrm{CsCl}$ solutions. J. Phys. Chem. 66: 1990-1998 (1962).

9. IFFT, J. B. and J. VINOGRAD: The buoyant behaviour of bovine serum mercaptalbumin in salt solutions at equilibrium in the ultracentrifuge. II. Net hydration, ion binding, and solvated molecular weight in various salt solutions. J. Phys. Chem. 70: 2814-2822 (1966).

10. IfFT, J. B. and A. E. Williams: The partial molar volumens of cesium and chloride ions in solution as a function of concentration. Biochim. Biophys. Acta 136: 151-153 (1967).

11. IFFT, J. B.: Proteins at sedimentation equilibrium in density gradients. In: P. AlexANDER and H. P. LUNDGREN, A Laboratory Manual of Analytical Methods of Protein Chemistry, Vol. 5, pp. 151227. Pergamon Press 1969.

12. IFF, J. B.: Proteins in density gradients. Methods Enzym. 27: 128-140 (1973).

13. IFFT, J. B.: The buoyant titration of native and carbamylated ovalbumin. Compt. Rend. Trav. Lab. Carlsberg 38: 315-338 (1971).

14. IfFT, J. B. and L. G. LuM: The potentiometric titration of native ovalbumin in concentrated $\mathrm{CsCl}$ solutions. Compt. Rend. Trav. Lab. Carlsberg 38: 339-349 (1971),

15. IMAHORI, K. and N. A. NiCOLA: Optical rotatory dispersion and the main chain conformation of proteins. In: S. J. LeaCH, ed., Physical Principles and Techniques of Protein Chemistry, Part C, pp. 357-444. Academic Press 1973.

16. Katz, S., J. K. Crissmann, Jr. and J. A. Beall: Structure-volume relationships of proteins. J. Biol. Chem. 248: 4840-4845 (1973).

17. KING, T.P. and M. SpENCER: Structural studies and organic ligandbinding properties of bovine plasma albumin. J. Biol. Chem. 245: 6134-6148 (1970).
18. Kuntz, I. D. and W. Kauzmann: Hydration of proteins and polypeptides. Adv. Prot. Chem. 28: 239-345 (1974).

19. Leonard, W. J., Jr., K. K. ViJal and J. F. Foster: A structural transformation in bovine and human plasma albumins in alkaline solution as revealed by rotatory dispersion studies. J. Biol. Chem. 238: 1984-1988 (1963)

20. Ruark, J. E. and IfFT, J. B.: The buoyant and potentiometric titrations of human immuno-gamma globulin. Biopolymers 14:1161-1171 (1975)

21. Sharp, D. S., R. Almassy, L. G. Lum, K. Kinzie, J.S.V. ZIL and J. B. IFFT: Buoyant and potentiometric titrations of synthetic polypeptides. II. Five copolypeptides and two non-ionizable homo polypeptides in $\mathrm{CsCl}$ solutions. Biopolymers 15: 757-783 (1976).

22. Spackman, D. H., W. H. Stein and S. Moore: Automatic recording apparatus for use in the chromatography of amino acids. Anal. Chem. 30: 1190-1206 (1958).

23. Spahr, P. F. and J. T. Edsall: Amino acid composition of human and bovine serum mercaptalbumin. J. Biol. Chem. 239: 850-854 (1964).

24. Tanford, C., S. A. Swanson and W. S. Shore: Hydrogen ion equilibria of bovine serum albumin. J. Amer. Chem. Soc. 77: 6414-6421 (1955).

25. VIJAI, K. K. and J. F. Foster: The amphoteric behaviour of bovine plasma albumin. Evidence for masked carboxylate groups in the native protein. Biochemistry 6: 1152-1159 (1967).

26. Williams, A.E. and J. B. IFFT: The buoyant titration of bovine serum mercaptalbumin. I. An interpretation in terms of ion binding. Biochim. Biophys. Acta 131: 311-318 (1969).

27. ZuRaWski, V. R., J J and J. F. Fosier: The neutral transition and the environment of the sulfhydryl side chain of bovine plasma albumin. Biochemistry 13: 3465-3471 (1974). 